\title{
Impulse Control Disorders in Parkinson's Disease. A Brief and Comprehensive Review
}

\author{
Emilia M. Gatto ${ }^{1,2 *}$ and Victoria Aldinio ${ }^{1}$ \\ ${ }^{1}$ Department of Neurology, Sanatorio de la Trinidad Mitre, Buenos Aires, Argentina, ${ }^{2}$ Instituto de Neurociencias Buenos \\ Aires, Ineba, Buenos Aires, Argentina
}

Impulse control and related disorders (ICDs-RD) encompasses a heterogeneous group of disorders that involve pleasurable behaviors performed repetitively, excessively, and compulsively. The key common symptom in all these disorders is the failure to resist an impulse or temptation to control an act or specific behavior, which is ultimately harmful to oneself or others and interferes in major areas of life. The major symptoms of ICDs include pathological gambling (PG), hypersexualtiy $(\mathrm{HS})$, compulsive buying/shopping $(\mathrm{CB})$ and binge eating (BE) functioning. ICDs and ICDs-RD have been included in the behavioral spectrum of non-motor symptoms in Parkinson's disease (PD) leading, in some cases, to serious financial, legal and psychosocial devastating consequences. Herein we present

OPEN ACCESS

Edited by:

Angelo Antonini,

University of Padova, Italy

Reviewed by:

Giovanna Calandra-Buonaura,

University of Bologna, Italy Eleonora Fiorenzato,

IRCCS Fondazione Ospedale

San Camillo, Italy

*Correspondence:

Emilia M. Gatto

emiliamgatto@gmail.com

Specialty section:

This article was submitted to

Movement Disorders,

a section of the journal

Frontiers in Neurology

Received: 02 August 2018

Accepted: 22 March 2019

Published: 17 April 2019

Citation:

Gatto EM and Aldinio V (2019) Impulse Control Disorders in Parkinson's

Disease. A Brief and Comprehensive

Review. Front. Neurol. 10:351.

doi: 10.3389/fneur.2019.00351 the prevalence of ICDs, the risk factors, its pathophysiological mechanisms, the link with agonist dopaminergic therapies and therapeutic managements.

Keywords: impulse control disorders, ICD, pathological gambling, binge eating, hypersexual disorder, compulsive buying, Parkinson disease

\section{DEFINITION}

Impulse control and related disorders (ICDs-RD) encompass a heterogeneous group of disorders that involve pleasurable behaviors performed repetitively, excessively, and compulsively (1-8).

The common key symptom in all of these disorders is the failure to resist an impulse or temptation to control an act or specific behavior $(1,3,9)$, which is ultimately harmful to oneself or others and interferes in major areas of life functioning $(1,3,6,10,11)$.

The American Psychiatric Association's Diagnostic and Statistical Manual (DSM-5) included impulse control disorders (ICDs) in the chapter of "Disruptive, Impulse-Control, and Conduct Disorders" as a dysregulation of self-emotional and behavioral control (8).

ICDs have recently been sub-classified as ICD groups and ICD-related disorder (ICDs-RD) groups $(1,3,6,7)$.

The major symptoms of ICDs include pathological gambling (PG), hypersexuality (HS), compulsive buying/shopping (CB) and binge eating (BE) (1-4, 8, 9, 12-21).

However, PG was moved from the category of ICDs to a new category of "Substance-Related and Addictive Disorders" in the DSM-5 $(1-3,6,7)$, taking into account the similarities to drug addiction (risk factors, clinical features, cognitive changes, neurobiological substrates, and treatment approaches) $(2,6)$. This modification highlights the variability of reward-driven behaviors $(2,6,16,22)$.

The spectrum of ICDs-RD also includes punding, hobbyism, walkabout, hoarding, and compulsive medication use. 
ICDs and ICDs-RD have been included in the behavioral spectrum of non-motor symptoms in Parkinson's disease (PD), leading in some cases to serious financial, legal and psychosocially devastating consequences with a greater impact on the quality of life. Moreover, in recent years we have noticed that PD patients are at increased risk of developing more than one of the major ICDs.

Along these lines, although it is not the focus of the present paper, some authors have suggested that the increased drive or motivation to certain behaviors cannot be harmful but rather beneficial (1). Therefore, it remains under discussion whether artistic productivity or hypercreativity should be included in ICDs or in ICDs-RD, or if it might represent an innateskill that emerges in $\mathrm{PD}$ patients on dopaminergic therapy $(8,12,13,23,24)$.

\section{COMPONENT ASPECTS}

Three main aspects that characterize ICDs groups and ICDrelated disorders in relation to reward-driven activities are:

1. The presence of impulsive aspects (lack of forethought or consideration of consequences) $(1,3,9)$.

2. The presence of compulsive aspects (repetitive behaviors with a lack of self-control) $(1,3,9)$.

3. A negative or harmful behavior to oneself or to others $(1,3,6)$.

The four major ICDs include:

Pathological Gambling (PG) characterized by an excessive and uncontrollable "preoccupation with gambling and the excitement that gambling with increasing risk provides" despite financial loss and social problems (3, 7, 22, 25-27). PG was one of the earliest recognized ICDs in PD (3). It was recently moved to the category of "Substance-related and addictive disorders" in the DMS-5, since substance abuse and PG activate brain reward areas and this bears similarities to drug addiction $(7,28)$.

Hypersexual disorder (HS) included in "The Sexual and Gender Identity Disorders Workgroup" of DSM-5 (7). It could be described as an excessive amount of time consumed by sexual fantasies and by planning for engaging in sexual behavior which interferes with important activities and obligations in ordinary life $(3,7)$. Other behaviors that might often occur are fetishism and voyeurism (7). As in substance abuse, patients with HS pursue a short-term reward and may develop tolerance and withdrawal-like syndromes (7). This condition is more common among adult men, and it may additionally occur with erectile failure $(6,7,9,17,29)$.

Binge eating has been included in "Feeding and Eating Disorders" in DSM-5 $(3,6,7)$. It is "a persistent disturbance of eating or eating-related behavior that results in the altered consumption of food, which significantly impairs physical health or psychosocial functioning" (7). The specific criteria proposed are:

1. Episodes of recurrent binge eating in the absence of any maladaptive compensatory behaviors.

2. Sense of lack of control over eating during the episodes.
3. Intake, in a discrete period of time (within any $2 \mathrm{~h}$ period), of an amount of food that is much larger than most people would eat in a similar period of time under normal circumstances.

The difference between binge eating and bulimia is that the former tends to be fluctuating while the latter is permanent $(3,7)$.

Compulsive buying (CB) is characterized by a constant urge to buy that leads to senseless contraction of debts with continuous delay of payment until a catastrophe clears the situation. As other ICDs, the repetitive loss of control over spending and the negative emotional state that emerges when not buying resemble substance use disorders $(3,7)$.

A prevalence of $5.8 \%$ in the general population at risk of $\mathrm{CB}$ is described $(1,3)$.

\section{ICD-RELATED BEHAVIORS (ICDs-RD)}

ICDs-RD are classified as related behaviors that have a contrast clinical presentation with respect to the four major ICDs. However, the biological link between both conditions may be identified in the dysregulation or inappropriate regulation of the reward pathways in the mesocorticolimbic network $(22,30)$. ICDs-RD is characterized by repetitive perseverative behaviors that appear to be more closely linked to pulsatile drugs, such as levodopa or intermittent apomorphine therapy rather than dopaminergic agonist (DA) per se.

ICDs-RD include the following:

1. Dopamine dysregulation syndrome (DDS) is a drug addiction-like state characterized by a compulsive and excessive desire for use of high potency and shortacting dopaminergic medication (L-dopa, subcutaneous apomorphine) $(1-4,6-8,12,13,15,17-22,30,31)$. DDS is more frequent in early-onset male PD patients with history of mood disorders and family history of psychiatric disorders $(26,31)$.

2. Punding is characterized by repetitive, purposeless behaviors and excessive preoccupation with specific items or activities, collecting, arranging or taking objects apart $(1-4,6-8,12,15$, 17-21, 26, 32). It has been reported to occur frequently in conjunction with DDS (32).

3. Hobbyism pertains to higher-level repetitive behaviors (sports, artistic endeavors) $(1,2,4,6,8,15,17-21)$.

4. Walkabout is excessive aimless wandering $(1,2,4,7,8,12,15$, 17, 19-21, 26).

5. Hoarding is the acquisition of and failure to discard a large number of items with no objective value $(1-4,6,7,12)$, $(8,15,18,21)$.

\section{EPIDEMIOLOGY}

\section{ICD in the General Population}

The prevalence of ICDs in the general population, which has been underestimated, shows a wide range with variability according to different populations: from 0.2 to $5.3 \%$ (1). This enormous variability may be explained not only by different genetic, ethnic and cultural backgrounds, but also by the 
TABLE 1 | Shows the estimated prevalence of each of the four major ICDs.

\begin{tabular}{|c|c|c|c|c|}
\hline ICDs & $\begin{array}{l}\text { General } \\
\text { population }\end{array}$ & $\begin{array}{l}\text { Dominion study } \\
\text { ICD subgroup }\end{array}$ & $\begin{array}{l}\text { ICARUS study (at } \\
\text { baseline, use QUIP) } \\
\text { ICD subgroup }\end{array}$ & $\begin{array}{l}\text { The drug interaction with } \\
\text { genes in Parkinson's disease } \\
\text { DIGPD study (ICD at baseline) }\end{array}$ \\
\hline Age (mean SD) & $N / A^{*}$ & $60.2(8.1)$ & $63.6 \pm 9.5$ & $58.5(8.9)$ \\
\hline UPDRS III score (mean SD) & & $\mathrm{N} / \mathrm{A}$ & $14.1 \pm 5.89$ & $18.8(9.4)$ \\
\hline $\begin{array}{l}\text { Cognitive scores MMSE adjusted total } \\
\text { score }\end{array}$ & & & $27.9 \pm 1.62$ & $28.4(1.7)$ \\
\hline Disease Duration & & $7.1(3.8-10.8)$ & $6.9 \pm 5.19$ & $3.1(1.4)$ \\
\hline Median dopamine agonist LEDD & & $300 \mathrm{mg}$ & $\mathrm{N} / \mathrm{A}$ & $211.1(118.0)$ \\
\hline Median levodopa LEDD associated DA & & $450 \mathrm{mg}$ & & $\mathrm{N} / \mathrm{A}$ \\
\hline $\begin{array}{l}\text { Median levodopa LEDD without a } \\
\text { dopamine agonist }\end{array}$ & & $621 \mathrm{mg}$ & & $263.4(230.7)$ \\
\hline Compulsive Buying & $5.8 \%(2-8)$ & $5.7 \%$ & $6.5 \%$ & $4.6 \%$ \\
\hline References & (1) & (29) & (19) & (33) \\
\hline
\end{tabular}

N/A*: non available or Non applicable.

instruments used to assess these symptoms in the population (3, 18-20) (Table 1).

Although the ICDs were initially reported in PD patients on DA therapies, some studies report the occurrence of ICDs in the general population and in novo PD patients $(10,11,34)$. It is still under discussion whether PD biology could be a risk factor for ICDs (35).

\section{ICD in de novo PD}

As mentioned above, it remains under discussion whether or not PD itself confers an increased risk for developing ICDs (35). Identifying the frequency of this disorder in novo PD patients could contribute to resolving these questions (1). A recent study analyzing data from the Parkinson's Progression Markers Initiative failed to demonstrate an increased risk for the development of ICDs or ICDs-RB in PD patients in the absence of treatment. Nevertheless, some symptoms suggestive of ICD have been reported in $20 \%$ of newly diagnosed, untreated PD patients with respect to the appropriately matched controls (36). In recent years, imaging studies have offered relevant insight to this debate (35). However, at the moment, results remain controversial over whether PD itself constitutes a risk factor for the development of ICDS or ICDs-RD $(1,3,6)$.

\section{ICDs-RD in PD in Different Populations}

ICDRs continue to be under-recognized and under-managed in clinical practice. Determining the true frequency of ICDs in the health population, in PD de novo patients, and in PD patients with and without DA agonist therapies in different populations represents a significant challenge since a number of variables must be analyzed, including assessment tools, DA dose, DA formulations, years of disease, as well as cultural and other factors. Moreover, in many cases more than one ICD has been identified (29). In Table 2 we present a summary of various studies conducted to assess the presence of ICD behaviors over different periods of time and evaluate the risk factors and clinical characteristics.

\section{Assessment Tools}

Several instruments have been developed to assess and identify ICD symptoms in PD, some of which are summarized in Table 3.

\section{Risk Factors}

Several studies have been conducted to identify the risk factors for ICD development in PD patients (8). They include:

+ Demographic: young patient, male gender, unmarried (3-8, 14-21, 24, 27, 29, 59, 60).

+ Treatment related: although ICDs have been reported to be associated to different drugs, such as L-dopa, amantadine and rasagiline, DA intake appears as the major risk factor for ICDs $(1-5,7,8,13-15,17-22,27,29,59,60)$.

Prevalence of ICDs was compared among different DA drugs (pramipexole, ropirinole) and between extended releases or immediate formulations $(1,3,6,29,60)$. However, controversial findings from preliminary reports suggest that long-acting DA and patch or pump formulations may reduce the risk for ICDs $(8,15,61)$.

It remains under discussion whether there is an association between ICDs and DA dose. The same controversial results were reported regarding DA treatment duration, higher daily dose and DA higher peak dose $(3,7,29,60)$.

+ Personal or family history: history of cigarette smoking, drug abuse, depression, apathy, REM behavior disorders (RBD), tea, coffee and mate consumption, positive personal or family history of alcoholism or gambling, and impulsive or novelty-seeking traits increase the risk for ICDs and their predictors $(2-8,14,16-18,29,59,60)$.

+ PD onset and related ICDs: prevalence increases over time, while ICDs tend to occur in the first years of 


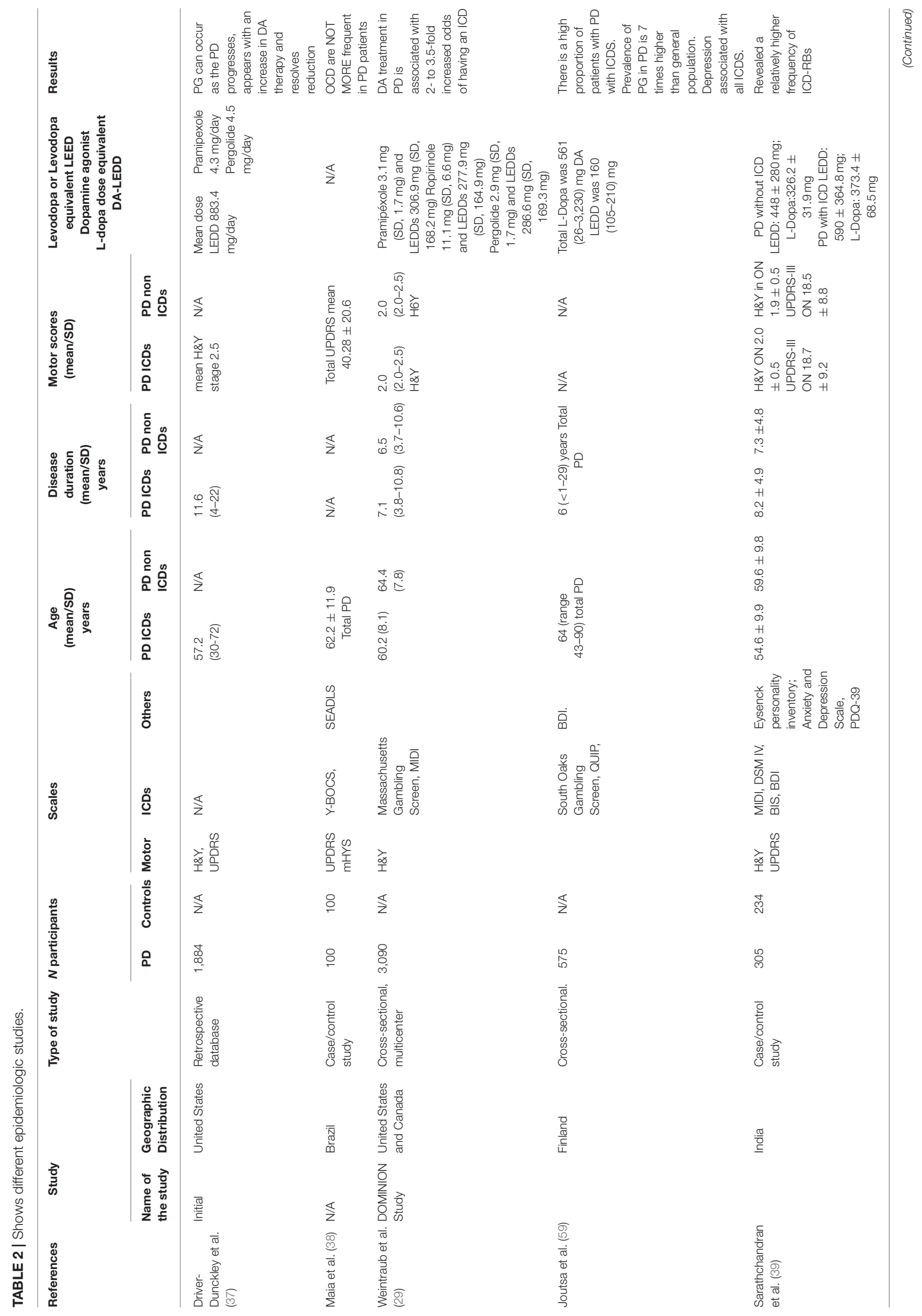




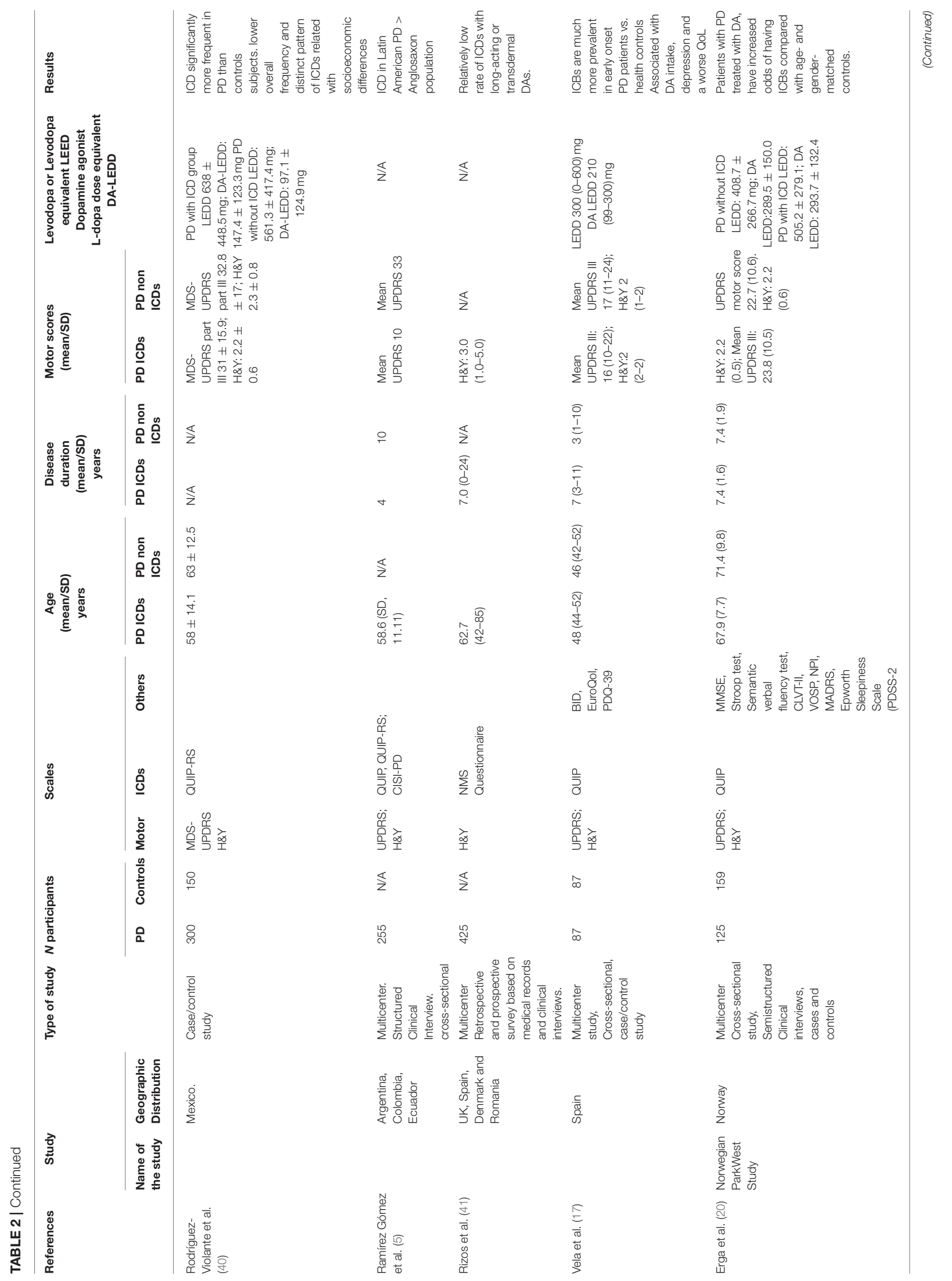




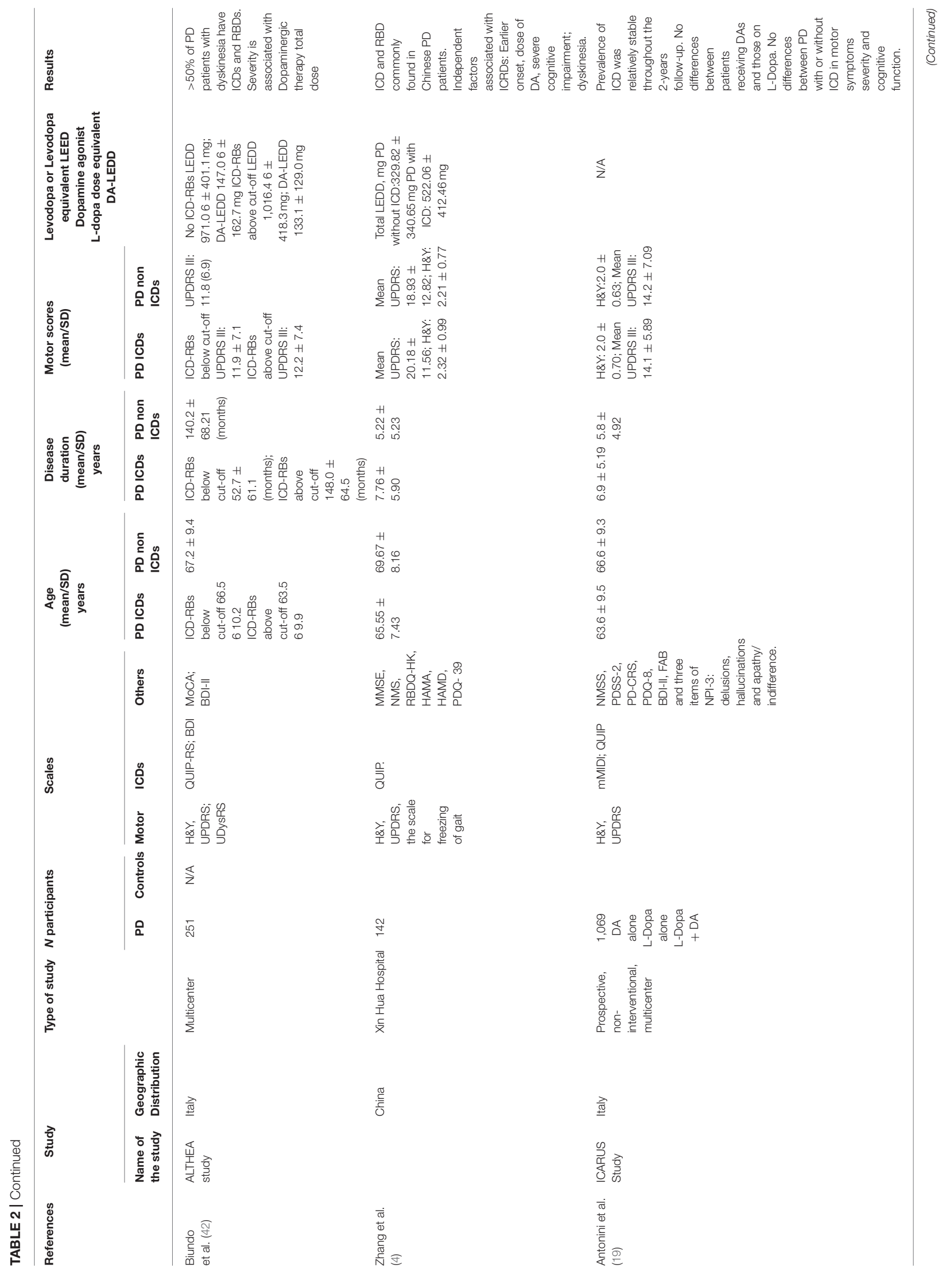




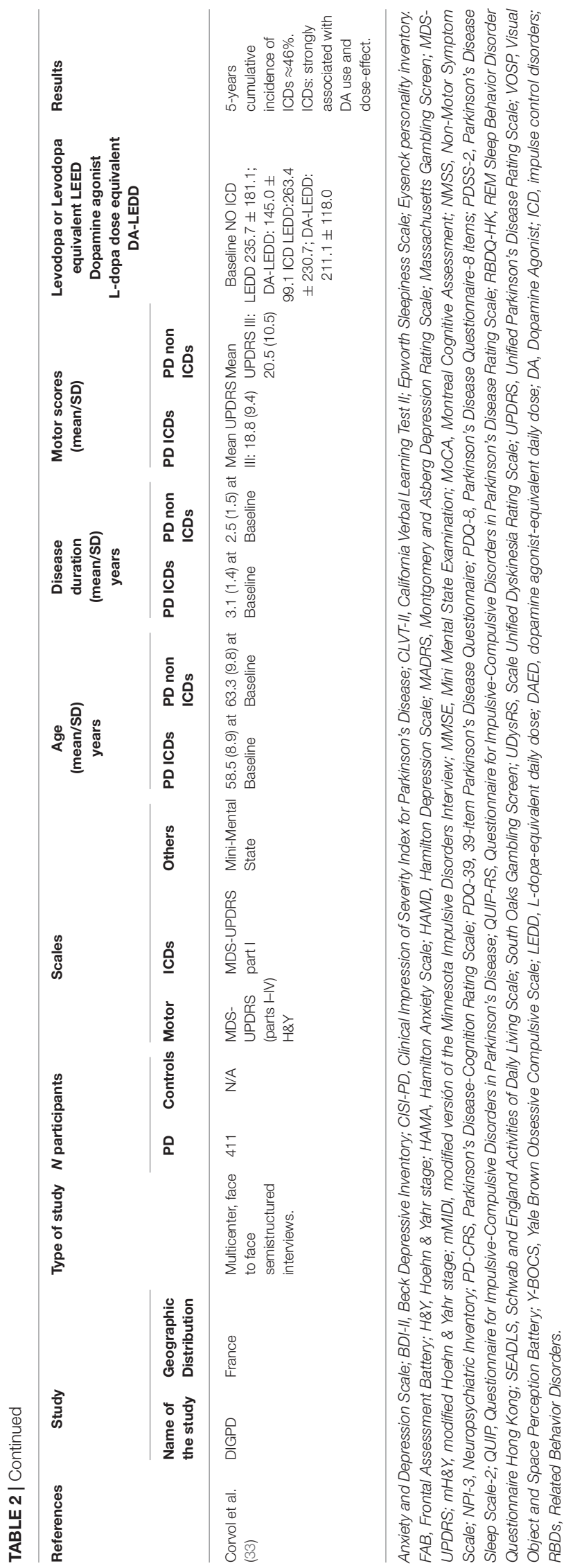

the disease. Early PD onset and the presence of motor complications of PD may predict a higher risk for ICDs $(4-8,13,14,16-18,21,24,29,60)$.

+ Cultural factors: it remains to be determined if cultural factors may increase the risk for ICDs and ICRDs. Some authors suggest that cultural factors probably contribute not only to the prevalence of ICD but also the type of $\operatorname{ICD}(7,17)$. One classic example in this field was provided by the DOMINIO study that suggests that living in the United States of America may be an independent risk factor for ICD development $(1,6,29)$.

+ Deep Brain Stimulation (DBS): the relationship between ICDs and DBS remain under discussion. Initial studies reported improvement in ICDs after DBS, while subsequent studies showed ICD exacerbation $(1,6,22,60,62)$.

DBS of the subthalamic nucleus (STN) is an effective, widely used treatment for motor fluctuations or disabling dyskinesias in PD (63).

STN-DBS has been identified as an independent risk factor for ICRDs; however, the reduction of dopamine agonist dosage after STN-DBS could improve or decrease ICD occurrence $(6,7,22,60,62)$.

On the other hand, several studies suggest that DBS may contribute to impulsivity, excessive reward seeking and ICDs. Consistent with this hypothesis, PD patients without ICDs showed impulsive decision making when DBS is turned on $(7,60,62,64)$.

To explain these controversial findings, it has been hypothesized that STN stimulation plays a role in dynamic aspects of impulse and inhibitory control $(22,60)$.

+ Personality, Neuropsychiatric symptoms and Cognition in ICDs: a higher level of neuroticism, ineffective coping skills, and lower levels of agreeableness and conscientiousness in PD patients with ICDs has been reported (3). Early onset PD patients constitute a high risk population for ICDs with a selfassertive/antisocial and reserved personality and somatization traits (22).

A large constellation of comorbid affective symptoms and behavioral traits have been reported in PD with/or at risk for ICDs including depression, anxiety, novelty seeking, impulsivity symptoms and anhedonia (2, 62, 65, 66). Interestingly, in PD patients with ICDs, apathy could be noticed during withdrawal from dopamine replacement therapy (DRT). Impulsivity and apathy are two major comorbid syndromes of $\mathrm{PD}$ that may represent two extremes of a dysexecutive and behavioral spectrum involving dopamine-dependent cortico-striatothalamo-cortical networks (64).

+ Cognition: controversial data have been identified in cognitive battery tests between PD patients with and without ICD $(8,36)$; the first group presents values lowered in some tests that evaluate the frontal lobe, but did not find significant differences in executive functioning $(14,67)$. Cognitive flexibility and ability to plan is altered in patients with ICD (8). Visuo-spatial working memory and reward-punishment learning impairments have been reported in different studies; however, many results could not be replicated $(6,17)$. 


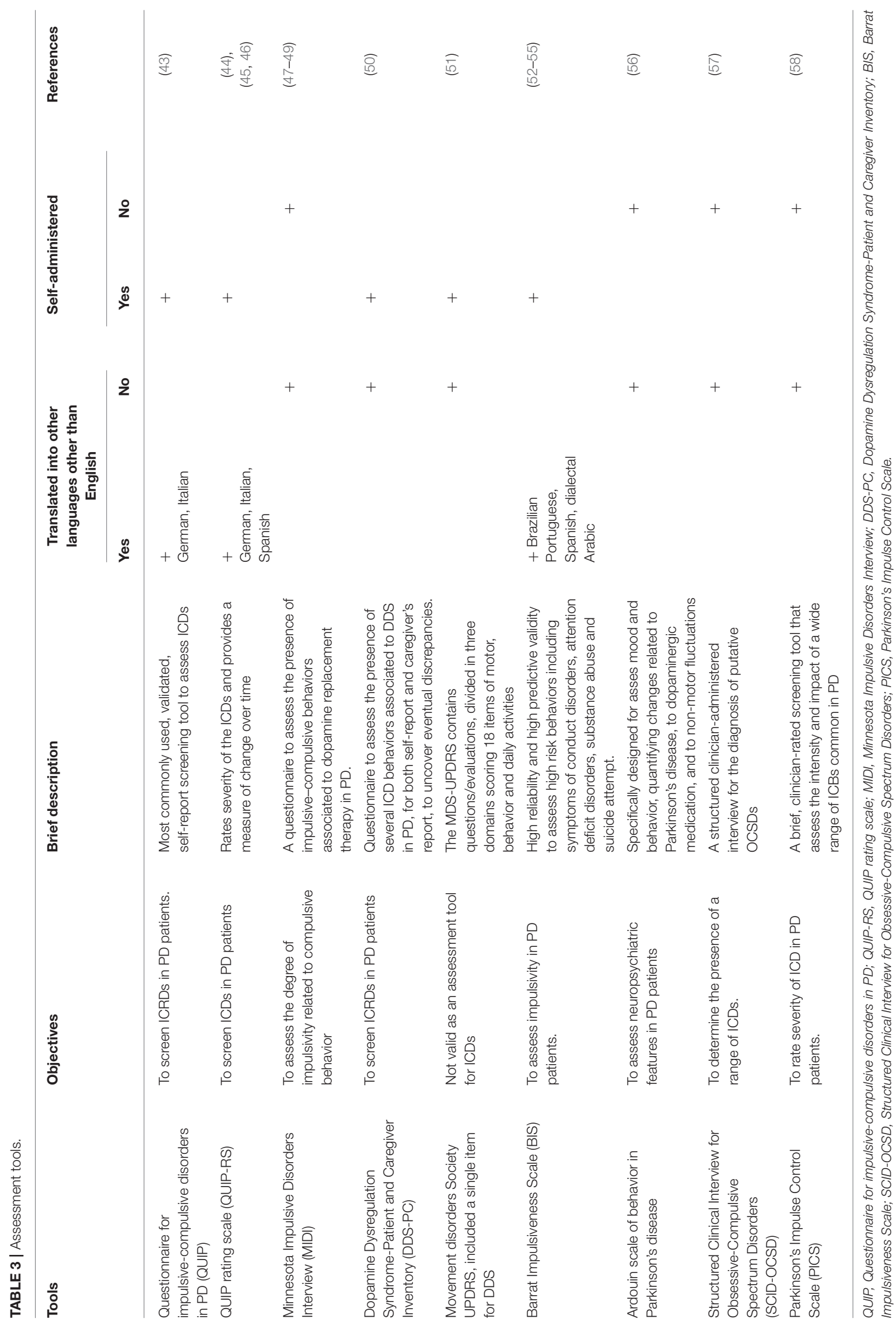


TABLE 4 | We present the genetic factors reported to be related to ICDs.

\begin{tabular}{|c|c|c|c|}
\hline Receptor types & Genotype & Associations & References \\
\hline \multirow[t]{8}{*}{ Dopamine } & DRD1rs4867798, rs4532, rs265981 & Increased risk of ICDs & $(9,71,72)$ \\
\hline & & $\begin{array}{l}\text { PD: punding and hobbyism behaviors, } \\
\text { ICDs }\end{array}$ & \\
\hline & & $\begin{array}{l}\text { Non-PD: ICDs, neuropsychiatric disease, } \\
\text { problem gambling, addiction, and } \\
\text { cognitive functioning in non-PD population }\end{array}$ & \\
\hline & DRD2 Taq1A Dopamine transporter (DAT1) & No association & (9) \\
\hline & DRD2/ANKK1 rs1800497 & Increased risk of ICDs & $(9,16,65,71)$ \\
\hline & $\begin{array}{l}\text { Dopa decarboxylase (DDC) rs 3837091; rs } \\
1451375\end{array}$ & Stronger predictor $\mathrm{f}$ ICDs & $(16)$ \\
\hline & D3Rp.S9G & ICDs and levodopa-induced dyskinesias & $(2,5,6,9,18,21,65,73)$ \\
\hline & & Stronger predictor of ICDs & \\
\hline Glutamate & Grin2B rs7301328 & Increased risk of ICDs & $(2,5,6,9,16,71)$ \\
\hline \multirow[t]{2}{*}{ Monoamine Transporters } & COMT gene Val158 Met & No association & $(9,65)$ \\
\hline & COMT rs4646318 & No association & (9) \\
\hline Opioid & OPRK1 rs702764 & Stronger predictor $\mathrm{f}$ ICDs & $(9,16,65,72)$ \\
\hline Serotonine & $\begin{array}{l}\text { Hydroxytryptamine receptor HTR2A } \\
\text { rs6313 }\end{array}$ & Stronger predictor $\mathrm{f}$ ICDs & $(2,6,8,9,16,18)$ \\
\hline
\end{tabular}

Interestingly, patients with ICDs showed a more immediate reward response and greater choice impulsivity leading to increased risk behavior (6).

When the cognitive performance was compared according to the type of ICD it was found that patients with HS showed greater general cognitive impairment, including lower performances on learning tests and were more impaired on the Stroop test and memory tasks than were patients with PG $(8,68)$. However, another study found no differences in the executive functions of patients with PD and PG (69).

+ Genetics: genetic factors have been involved in ICDs in PD. Although heritability was estimated to be $57 \%$, consensus remains a challenge and data need to be replicated in large cohorts from different populations (16). A large number of single nucleotide polymorphisms (SNP) in dopaminergic, glutamatergic, serotonergic, and opioid neurotransmitter systems has been reported as a candidate that improved predictability of ICDs when compared with clinical risk factors (2, 6, 9, 16, 21, 70). Recently, an association of OPRM1 rs1799971 was identified, a gene encoding the mu opioid receptor with ICDs. This gene is central to pain control as well as drug reward and addictive behaviors (70).

In Table 4 we present the genetic factors reported to be related to ICDs.

Interestingly, the ICARUS study, the largest prospective observational study in an Italian population, contributes to the identification of additional risk factors that include nonmotor symptoms (mood and sexual function), mood symptoms (depression), sleep disorders and a low level of quality of life (19).

\section{+Other Risk Factors}

Recently, the overexpression of $\triangle F$ osB, a transcriptional regulator involved in addiction induced by drugs of abuse and in many types of compulsive behaviors has been reported to be associated with L-dopa induced dyskinesia and to be triggered by pramipexole (60).

The $\triangle$ FosB overexpression was identified in the nucleus accumbens (NA) and the striatum (brain regions important for addiction) of healthy and DA-lesioned rats exposed to pramipexole and found to be NMDA receptor dependent. These findings suggest that enhanced $\Delta$ FosB expression may represent the strongest predictor of PD patients at risk of ICDs $(27,60)$.

\section{PATHOPHYSIOLOGY}

Although an extensive number of studies have focused on the pathophysiologic mechanisms of ICDs in PD, these remain to be clarified $(2,9)$. Classically, the appearance of impulsivity in PD has been attributed to neuronal dopaminergic degeneration, facilitating ICD occurrence in dopamine replacement therapies (8).

Nevertheless, in recent years, evidence has suggested a complex multifactorial mechanism beyond the dopaminergic corticostriatal networks, including a complex serotoninergic and noradrenergic interaction. Further investigation is required (9).

\section{DOPAMINERGIC THEORY}

Dopaminergic receptors, Dopamine 1 receptor 1 (D1R) (D1 and D5) and Dopamine 2 receptor (D2R) (D2, D3, D4) types possess contrasting roles with inhibitory and excitatory signaling, respectively. These contrasting roles are present not only in the nigro-striatal pathway but also in the mesolimbic and mesocortical circuits. The pathways link cortical and subcortical regions [prefrontal cortex (PFC), ventral striatum, VTA and amygdala]; both circuits are implicated in reward learning and executive decision making or reinforcement behaviors, respectively $(6,22,74)$. 
TABLE 5A | Structural MRI.

\begin{tabular}{|c|c|c|c|c|c|}
\hline Study objectives & \multicolumn{3}{|c|}{ Participants } & Results & References \\
\hline $\begin{array}{l}\text { To measure brain cortical } \\
\text { thickness and subcortical } \\
\text { volumes, and to assess their } \\
\text { relationship with presence and } \\
\text { severity of symptoms, in PD } \\
\text { patients with and without ICDs. }\end{array}$ & $x$ & $x$ & $x$ & $\begin{array}{l}\text { In ICD+: Significant cortical thinning in right superior } \\
\text { orbitofrontal, left rostral middle frontal, bilateral } \\
\text { caudal middle frontal region, and corpus callosum } \\
\text { and reduced volume in right accumbens and } \\
\text { increase in left amygdala in ICD }\end{array}$ & (84) \\
\hline $\begin{array}{l}\text { To identify Neuroanatomical } \\
\text { abnormalities in PD patients } \\
\text { with PG }\end{array}$ & $\begin{array}{l}\text { Pathological } \\
\text { Gambling (PG) }\end{array}$ & $x$ & $x$ & $\begin{array}{l}\text { Gray matter loss in bilateral Orbitofrontal-cortex in } \\
\text { PD-PG vs. PD-CNTR correlated with increase of } \\
\text { gambling symptoms in PD-PG }\end{array}$ & (85) \\
\hline $\begin{array}{l}\text { To assess whether a functional } \\
\text { dysregulation of the habenula } \\
\text { and amygdala (modulators of the } \\
\text { reward brain circuit), contributes } \\
\text { to PD punding. }\end{array}$ & X Punding & $x$ & $x$ & $\begin{array}{l}\text { Cortical thinning of right inferior frontal gyrus } \\
\text { compared to controls and PD-without punding }\end{array}$ & (87) \\
\hline $\begin{array}{l}\text { To investigate structural } \\
\text { abnormalities in mesocortical, } \\
\text { limbic cortices and subcortical } \\
\text { structures in PD ICDs. }\end{array}$ & $x$ & $x$ & $x$ & $\begin{array}{l}\text { Volume loss in the nucleus accumbens of PD } \\
\text { patients. PD-ICD showed significant increased } \\
\text { cortical thickness in rostral anterior cingulte cortex } \\
\text { and frontal pole compared to PD-without ICD. } \\
\text { Increased cortical thickness in medial prefrontal } \\
\text { regions in PD-ICD }\end{array}$ & (88) \\
\hline $\begin{array}{l}\text { To investigate gray matter (GM) } \\
\text { and cortical thickness (CTh) } \\
\text { changes in PD with and without } \\
\text { ICDs. }\end{array}$ & $x$ & $x$ & $x$ & $\begin{array}{l}\text { Increased cortical thickness in anterior cingulate } \\
\text { cortex, orbitofrontal cortex in PD-ICD. }\end{array}$ & (91) \\
\hline $\begin{array}{l}\text { Morphometric Changes in PD } \\
\text { punding patients }\end{array}$ & Punding & $x$ & $x$ & $\begin{array}{l}\text { Significant cortical thinning in dorsolateral prefrontal } \\
\text { cortex in PD-punding. Cortical thinning in } \\
\text { PD-punders localized in prefrontal cortex extending } \\
\text { into orbitofrontal cortex. }\end{array}$ & (92) \\
\hline
\end{tabular}

Modified by: Ramdave et al. (81) and Meyer et al. (82).

Anatomical regions involved in ICDs:

1. Planning and judgment areas: caudal orbitofrontal cortex, ventromedial prefrontal cortex (PFC).

2. Reward system: ventral striatum (VS-nucleus accumbens [NA]).

3. Conditioned responses and emotional processing: amygdala.

4. Medial dorsal and anterior nucleus of the thalamus $(6,75)$.

In $\mathrm{PD}$ with ICDs a marked decrease ventrostriatal D3Rbinding has been reported, while experimental PD models have shown an increase in DA levels in the NA associated to bilateral nigrostriatal DA denervation $(64,76)$. These findings, of a diminished striatal D2/D3 receptor level and an increase in mesolimbic DA tone, lead to an imbalance in the cortico-accumbens network implicated in reward signaling and behavioral changes $(64,77,78)$. Moreover, the dopaminergic mesocorticolimbic system provides a role for shift behavior in response to changing stimulus-reward contingencies (64).

In this scenario, the tonic "overdosed" by D2/D3 receptor agonists in the mesocorticolimbic circuit could contribute to suppress, through the impairment of top-down inhibitory control from prefrontal cortical area (PFC) inputs to the 
TABLE 5B | Diffusion-tensor images.

\begin{tabular}{|c|c|c|c|c|c|}
\hline Study objectives & \multicolumn{3}{|c|}{ Participants } & Results & References \\
\hline $\begin{array}{l}\text { To assess brain white matter } \\
\text { tract alterations in PD+ punding } \\
\text { vs. controls and PD ICD, and PD } \\
\text { non-ICD }\end{array}$ & PD + Punding & PD Punding - & $x$ & $\begin{array}{l}\text { Greater damage of genu of corpus callosum and left } \\
\text { pedunculopontine tract in PD-punding vs. } \\
\text { PD-without ICD }\end{array}$ & (93) \\
\hline $\begin{array}{l}\text { To identify alterations of white } \\
\text { matter tract in drug-naïve PD- } \\
\text { ICDs }\end{array}$ & $x$ & $x$ & $x$ & $\begin{array}{l}\text { Decreased connectivity in left and right } \\
\text { cortico-thalamic tract, left and right cortico-pontine } \\
\text { tract, left and right corticospinal tract, left and right } \\
\text { superior cerebellar peduncle and left and right } \\
\text { middle cerebellar peduncle between PD-ICD } \\
\text { compared to PD-without ICD. Decreased } \\
\text { connectivity in left and right inferior longitudinal } \\
\text { fasciculus, genu and body of corpus callosum, left } \\
\text { and right corticospinal tract, left superior cerebellar } \\
\text { peduncle and left and right cingulum in PD-ICD } \\
\text { compared to control. }\end{array}$ & (94) \\
\hline
\end{tabular}

Modified by: Ramdave et al. (81) and Meyer et al. (82).

ventral striatum, reward-related learning and induce compulsive, perseverative behavior through the direct D1 receptor pathway $(6,9,22)$.

Dopaminergic agonists (DA) show a high D3R affinity in the mesolimbic system $(6,7,9,60)$. In effect, DA therapy, acting on the depleted dorsal striatum (involved in the sensorymotor circuit) and a relatively intact ventral striatum, induces a reduction of inhibitory response and impulse control by the reduction of activity in the lateral orbitofrontal cortex, the rostral cingulated zone, the amygdala, and in the external pallidum $(6,7)$. Therefore, PD patients on DA are not only at high risk for ICDs but also demonstrate greater choice impulsivity, shorter reaction time and increased risk taking $(6,79)$.

The D1 receptor family localize in the direct pathway of reward-based behaviors. Stimulation increases the activity of striatal projections to the nucleus accumbens/ventral striatum, while D2 receptors elicit suppression of the cortico-accumbens network $(6,22,80)$.

\section{NEUROIMAGING IN PD PATIENTS WITH ICDS}

In recent years neuroimaging, particularly that which is focused on the dopaminergic system, has significantly contributed to the knowledge of neurobiological factors for $\operatorname{ICDs}(2,7,8,81,82)$ (see Tables 5A-D).

\section{STRUCTURAL AND FUNCTIONAL MAGNETIC RESONANCE IMAGING}

1. Structural MRI changes have been reported in PD patients with ICDs with a selective atrophy in the orbitofrontal and anterior cingulate cortices (areas involved in behavioral modulation). Atrophy in the orbitofrontal cortex has been reported in PD patients with $\operatorname{ICDs}(85,91)$.

2. Functional brain resonance (fMRI) studies have reported an abnormal metabolism on the frontostriatal and cingulate cortices, the nucleus accumbens and the amygdala $(2,120)$.

3. A connectivity dysfunction between the striatal and limbic areas has been proposed. Brain connectivity was impaired in PD patients with ICDs with respect to the PD individuals without ICDs involving the neurocognitive network. A decreased connectivity has been identified in the central executive networks (mediofrontal areas, anterior cingulate and para-cingulate cortices), while an increased connectivity has been identified in the salience network (limbic-paralimbic network) and in the default mode network (pre-cuneus and posterior cingulate, bilateral inferior-lateral-parietal and ventromedial frontal cortices) $(95,97)$.

Single photon emission computed tomography (SPECT) of the dopamine transporter (DAT).

DAT regulates dopamine turnover. A reduced DAT binding in PD patients with PG and ICDs has been identified in PD patients 


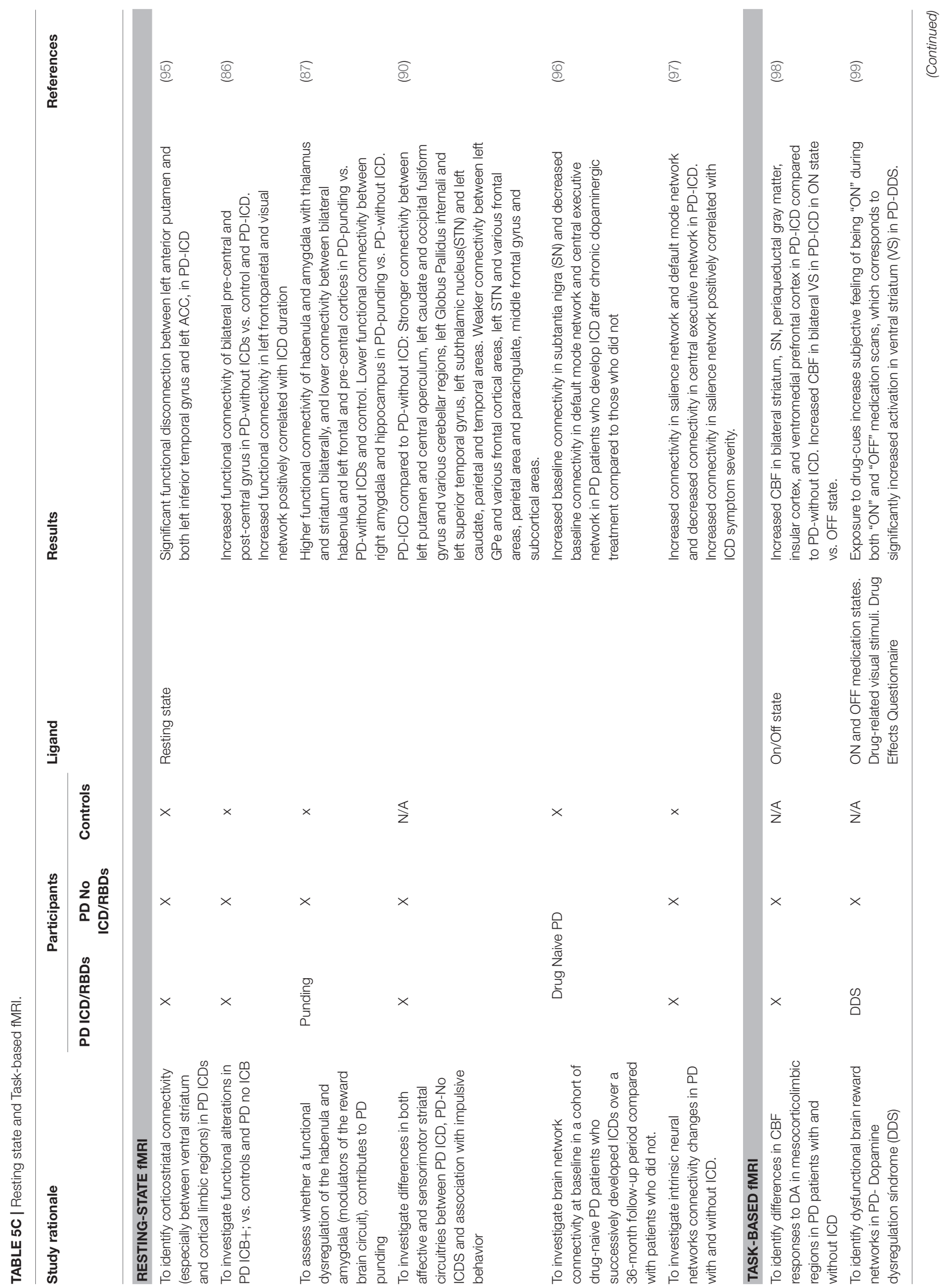




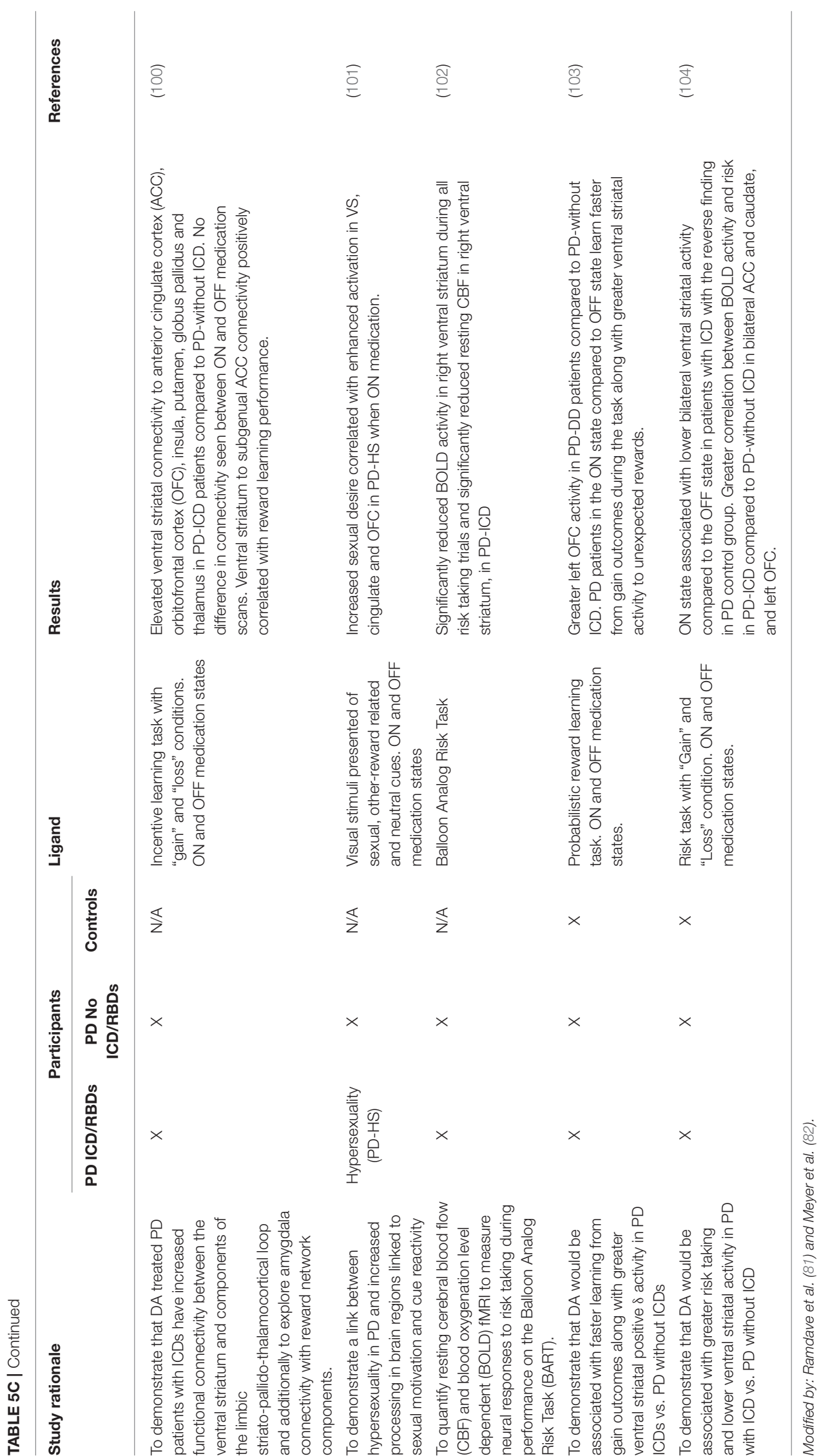




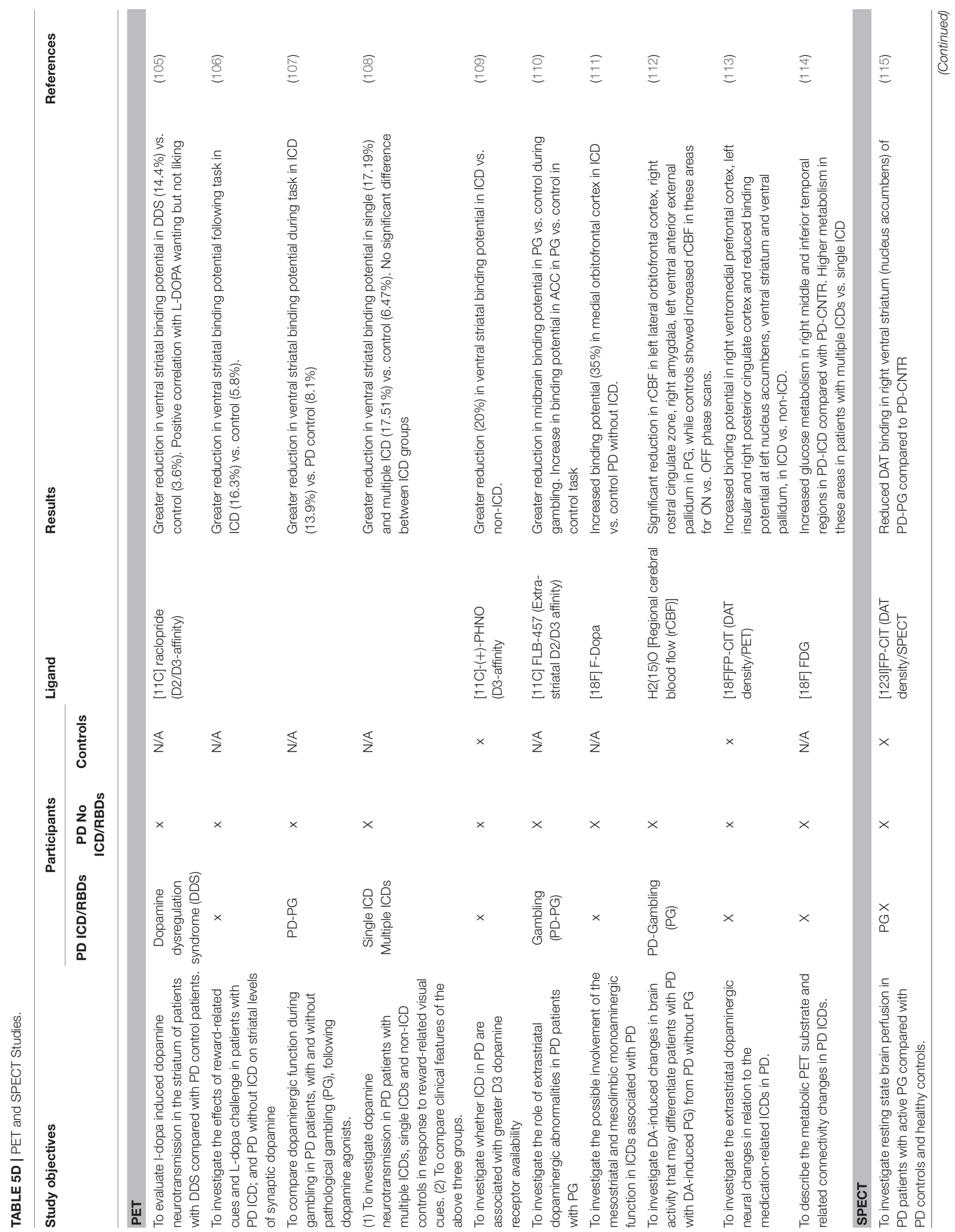




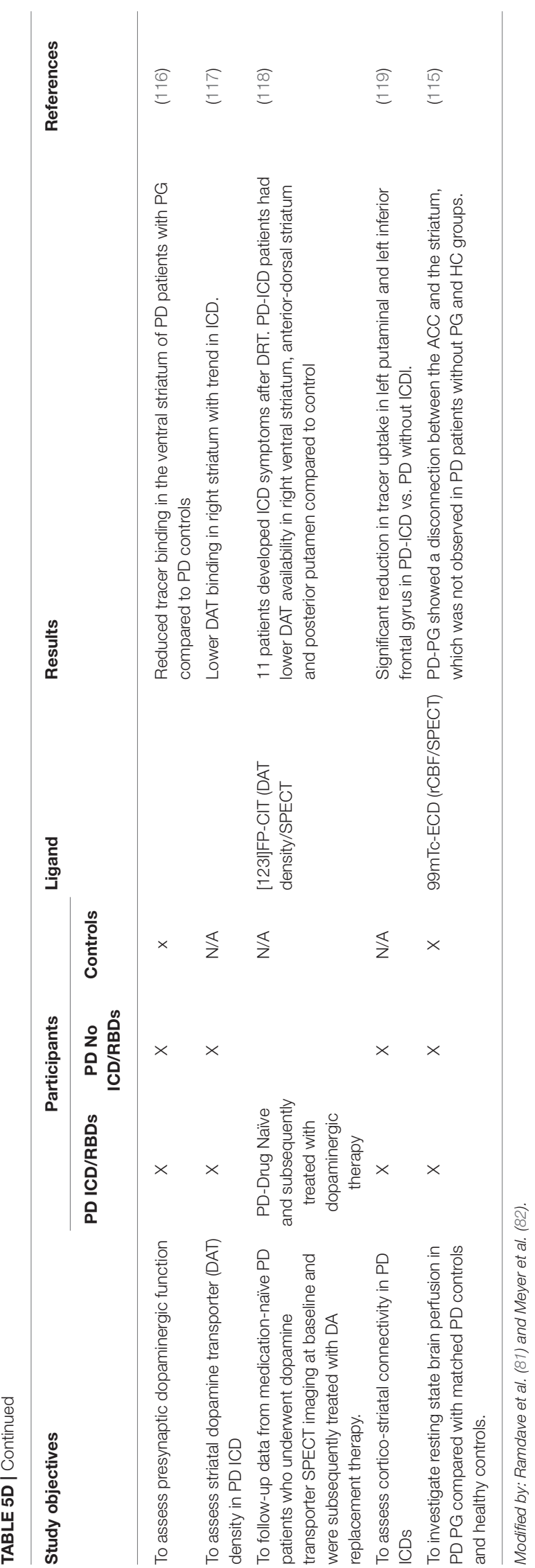

with ICD compared to PD patients without ICD or healthy controls. This reduced binding of DAT has been suggested as a potential biomarker for risk of developing ICD symptoms $(2,36,60)$. The binding reduction was not uniformly reproduced in different studies: some reported a reduction in right ventral striatum $(2,102)$, while others in the left putamen and left inferior frontal gyrus. These data could reflect a mesolimbic projection and frontostriatal disconnection, suggesting a vulnerability or maladaptive synaptic plasticity under non-physiological DA stimulation (2).

\section{POSITRON EMISSION TOMOGRAPHY (PET) WITH 11C-RACLOPRIDE}

Positron emission tomography (PET) neuroimaging with 11Craclopride explores the DA fluxes within the basal ganglia. The 11C-raclopride is a reversible binding to the postsynaptic D2/3 receptor that competes with endogenous DA $(2,8,22,106,107)$. Decreased 11C-raclopride binding is an indirect measure of increased endogenous dopamine release or "hyperdopaminergic state."

A significant reduction of 11C-raclopride binding has been reported in ventral striatum, but not in dorsal striatum, in PD with ICDs (single or multiple) as compared to PD individuals without ICDs, following generic reward-related vs. neutral visual stimuli.

A more selective radioligand $[18 \mathrm{~F}]$ fallypride, with high affinity D2-like receptors (D2/D3 receptors) confirmed a reduced binding within the VS and putamen (121).

All of these findings contribute to support a mesocorticolimbic imbalance in PD with ICDs (108).

\section{PD- ICDs TREATMENT}

The first approach for ICD is prevention, and a key element is patient and family education concerning potential risks of different dopaminergic therapies. Physicians should be aware of predisposing risk factors and balance cost/benefit before DA prescriptions, excluding genetic factors and taking into consideration clinical findings, such as young age, early PD onset, lengthy disease duration, personal history of addictive behaviors, male gender, short-acting DA drugs, behavior and mood disorders (apathy, depression), DBS and certain cultural factors that require attention before prescription.

When ICDs appear, treatment continues to be a challenge. Individualized treatment must be conducted, identifying potential variables, such as motor status, comorbidities, other non-motor symptoms and quality of life $(27,122,123)$.

The relevance of prevention is supported by NICE guidance that includes written information, or verbal information recorded in writing, at DA initiation of treatment. The authors emphasize the relevance of communicating to patients, relatives and carers the risk of ICDs due to the potential impact on their lives and for early detection (124).

The first approach for the treatment of ICD symptoms is the reduction or discontinuation of DAs. However, it should be 
considered that neuropsychiatric traits may persist for at least 12 weeks after drug withdrawal $(60,61,123)$.

Nonetheless, in certain cases this strategy is not feasible, and some patients are at risk of developing DA withdrawal syndrome and worsening motor symptoms $(21,61,123)$.

Although animal PD models have identified serotonin (5HT) depletion as a higher risk for impulsivity and risk behaviors, the serotonin reuptake inhibitors (SSRIs) used to treat ICDs had controversial results $(22,123)$.

Atypical antipsychotics, such as clozapine and quetiapine have been used to treat ICDs in PD, but no randomized trials have been conducted and evidence is limited $(2,7)$.

Taking into consideration that specific SNP opioid receptors have been identified as stronger risk factors for ICDs, opioid antagonists employed in the treatment of PG have produced controversial results (naltrexone, nalmefene) $(2,7,16,22,60,123)$.

A number of drugs administered to increase Gabaergic inhibition (valproate, topiramate), as well as new drugs to preserve ventral striatal DA system (zonisamide, donepezil, noradrenaline reuptake inhibitor) have been essayed (2).

As previously mentioned, controversial data are available concerning DBS and ICD treatment. A favorable response through reduction in dopaminergic requirements has been noted. It has been suggested that STN stimulation could reduce

\section{REFERENCES}

1. Weintraub D, David AS, Evans AH, Grant JE, Stacy M. Clinical spectrum of impulse control disorders in Parkinson's disease. Mov Disord. (2015) 30:121-7. doi: $10.1002 / \mathrm{mds} .26016$

2. Jiménez-Urbieta $H$, Gago $B$, de la Riva $P$, Delgado-Alvarado $M$, Marin C, Rodriguez-Oroz MC. Dyskinesias and impulse control disorders in Parkinson's disease: from pathogenesis to potential therapeutic approaches. Neurosci Biobehav Rev. (2015) 56:294-314. doi: 10.1016/j.neubiorev.2015.07.010

3. Maloney EM, Djamshidian A, O'Sullivan SS. Phenomenology and epidemiology of impulsive-compulsive behaviours in Parkinson's disease, atypical Parkinsonian disorders and non-Parkinsonian populations. J Neurol Sci. (2017) 374:47-52. doi: 10.1016/j.jns.2016.12.058

4. Zhang Y, He A, Li L, Chen W, Liu Z. Clinical characteristics of impulse control and related disorders in Chinese Parkinson's disease patients. BMC Neurol. (2017) 17:98. doi: 10.1186/s12883-017-0874-6

5. Ramírez Gómez CC, Dueñas MS, Bernal O, Araoz N, Sáenz Farret M, Aldinio $\mathrm{V}$, et al. A multicenter comparative study of impulse control disorder in Latin American patients with Parkinson disease. Clin Neuropharmacol. (2017) 40:51-5. doi: 10.1097/WNF.0000000000000202

6. Weintraub D, O Claassen D. Impulse control and related disorders in Parkinson's disease. Int Rev Neurobiol. (2017) 133:679-717. doi: 10.1016/bs.irn.2017.04.006

7. Cossu G, Rinaldi R, Colosimo C. The rise and fall of impulse control behavior Disorders. Parkinsonism Relat Disord. (2018) 46 Suppl. 1:S24-9. doi: 10.1016/j.parkreldis.2017.07.030

8. Marques A, Durif F, Fernagut PO. Impulse control disorders in Parkinson's disease. J Neural Transm. (2018) 125:1299. doi: 10.1007/s00702-0181870-8

9. Bhattacharjee S. Impulse control disorders in Parkinson's disease: pathophysiology, effect of genetic polymorphism and future research directions. Austin J Clin Neurol. (2017) 4:1100. doi: 10.4103/0028-3886.237019 the risk for ICDs by increased reward-driven behaviors by inhibitor effect in the indirect dopaminergic pathway. However, some patients may develop transient de novo ICDs after STN DBS, and selective patients may develop ICDs a long time after DBS $(123,125)$.

A non-pharmacologic approach includes cognitive behavioral therapy and patient and caregiver education $(7,60)$.

\section{CONCLUSIONS}

The treatment used for PD, particularly DA, is associated with the development of ICDs and related behaviors. Susceptibility to these disorders depends on the associated risk factors.

ICDs can have serious personal, family, psychosocial, financial, and medical consequences. However, in contrast, artistic activities have been described in patients with PD while undergoing treatment with DA. These patients are compulsive but report a positive influence on quality of life.

These findings highlight the need for a very critical approach at the moment of Dopaminergic Replacement therapy choice.

\section{AUTHOR CONTRIBUTIONS}

EG: study concept, design, and editing. VA: study concept and editing of manuscript.

10. Müller A, Rein K, Kollei I, Jacobi A, Rotter A, Schütz P, et al. Impulse control disorders in psychiatric inpatients. Psychiatry Res. (2011) 188:434-8. doi: 10.1016/j.psychres.2011.04.006

11. Tamam L, Bican M, Keskin N. Impulse control disorders in elderly patients. Compr Psychiatry. (2014) 55:1022-8. doi: 10.1016/j.comppsych.2013.12.003

12. Joutsa J, Martikainen K, Kaasinen V. Parallel appearance of compulsive behaviors and artistic creativity in Parkinson's disease. Case Rep Neurol. (2012) 4:77-83. doi: 10.1159/000338759

13. López-Pousa S, Lombardía-Fernández C, Garre Olmo J, Monserrat-Vila S, Vilalta-Franch J, Calvó-Perxas L. Dopaminergic dysregulation, artistic expressiveness, and Parkinson's disease. Case Rep Neurol. (2012) 4:159-66. doi: $10.1159 / 000343946$

14. Bentivoglio AR, Baldonero E, Ricciardi L, De Nigris F, Daniele A. Neuropsychological features of patients with Parkinson's disease and impulse control disorders. Neurol Sci. (2013) 34:1207-13. doi: 10.1007/s10072-012-1224-5

15. Garcia Ruiz PJ, Martinez Castrillo JC, Alonso-Canovas A, Herranz Barcenas A, Vela L, Sanchez Alonso P, et al. Impulse control disorder in patients with Parkinson's disease under dopamine agonist therapy: a multicentre study. J Neurol Neurosurg Psychiatry. (2014) 85:841-5. doi: 10.1136/jnnp-2013-306787

16. Kraemmer J, Smith K, Weintraub D, Guillemot V, Nalls MA, CormierDequaire F, et al. Clinical-genetic model predicts incident impulse control disorders in Parkinson's disease. J Neurol Neurosurg Psychiatry. (2016) 87:1106-11. doi: 10.1136/jnnp-2015-312848

17. Vela L, Martínez Castrillo JC, García Ruiz P, Gasca-Salas C, Macías Macías Y, Pérez Fernández E, et al. The high prevalence of impulse control behaviors in patients with early-onset Parkinson's disease: a cross-sectional multicenter study. J Neurol Sci. (2016) 368:150-4. doi: 10.1016/j.jns.2016.07.003

18. Wang XP, Wei M, Xiao Q. A survey of impulse control disorders in Parkinson's disease patients in Shanghai area and literature review. Transl Neurodegen. (2016) 5:4. doi: 10.1186/s40035-016-0051-7

19. Antonini A, Barone P, Bonuccelli U, Annoni K, Asgharnejad M, Stanzione P. ICARUS study: prevalence and clinical features of impulse control disorders 
in Parkinson's disease. J Neurol Neurosurg Psychiatry. (2017) 88:317-24. doi: 10.1136/jnnp-2016-315277

20. Erga AH, Alves G, Larsenc JP, Tysnesd OB, Pedersena KF. Impulsive and compulsive behaviors in Parkinson's disease: the Norwegian ParkWest Study. J Parkinsons Dis. (2017) 7:183-91. doi: 10.3233/JPD-160977

21. Vriend C. The neurobiology of impulse control disorders in Parkinson's disease: from neurotransmitters to neural networks. Cell Tissue Res. (2018) 373:327. doi: 10.1007/s00441-017-2771-0

22. Lopez AM, Weintraub D, O Claassen D. Impulse control disorders and related complications of Parkinson's disease therapy. Semin Neurol. (2017) 37:186-92. doi: 10.1055/s-0037-1601887

23. Kulisevsky J, Pagonabarraga J, Martinez-Corral M. Changes in artistic style and behaviour in Parkinson's disease: dopamine and creativity. J Neurol. (2009) 256:816-9. doi: 10.1007/s00415-009-5001-1

24. Canesia M, Rusconib ML, Moronib F, Ranghettib A, Ceredac E, Pezzolia G. Creative thinking, professional artists, and Parkinson's disease. J Parkinsons Dis. (2016) 6:239-46. doi: 10.3233/JPD-150681

25. World Health Organization. International Classification of Diseases (ICD10): Clinical Descriptions and Diagnostic Guidelines. Geneva: World Health Organization (1992).

26. Giovannoni G, O'Sullivan JD, Turner K, Manson AJ, Lees AJL. Hedonistic homeostatic dysregulation in patients with Parkinson's disease on dopamine replacement therapies. J Neurol Neurosurg Psychiatry. (2000) 68:423-8. doi: 10.1136/jnnp.68.4.423

27. Vargas AP, Costa Cardoso FE. Impulse control and related disorders in Parkinson's disease. Arq Neuropsiquiatr. (2018) 76:399-410. doi: 10.1590/0004-282X20180052

28. Angioletti L, Siri C, Meucci N, Pezzoli G, Balconi M. Pathological gambling in Parkinson's disease: autonomic measures and impaired decision-making. Eur J Neurosci. (2018). doi: 10.1111/ejn.13993. [Epub ahead of print].

29. Weintraub D, Koester J, Potenza MN, Siderowf AD, Stacy M, Voon $\mathrm{V}$, et al. Impulse control disorders in Parkinson disease: a crosssectional study of 3090 patients. Arch Neurol. (2010) 67:589-95. doi: 10.1001/archneurol.2010.65

30. Warren N, O'Gorman C, Lehn A, Siskind D. Dopamine dysregulation syndrome in Parkinson's disease: a systematic review of published cases. J Neurol Neurosurg Psychiatry. (2017) 0:1-5. doi: 10.1136/jnnp-2017-315985

31. Pezzella FR, Colosimo C, Vanacore N, Di Rezze S, Chianese M, Fabbrini G, et al. Prevalence and clinical features of hedonistic homeostatic dysregulation in Parkinson's disease. Mov Disord. (2005) 20:77-81. doi: 10.1002/mds. 20288

32. Evans AH, Katzenschlager R, Paviour D, O'Sullivan JD, Appel S, Lawrence AD, et al. Punding in Parkinson's disease: its relation to the dopamine dysregulation syndrome. Mov Disord. (2004) 19:397-405. doi: $10.1002 / \mathrm{mds} .20045$

33. Corvol JC, Artaud F, Cormier-Dequaire F, Rascol O, Durif F, Derkinderen P, et al. Longitudinal analysis of impulse control disorders in Parkinson disease. Neurology. (2018) 91:e189-201. doi: 10.1212/WNL.0000000000005816

34. Kessler RC, Chiu WT, Demler O, Walters EE. Prevalence, severity, and comorbidity of 12-month DSM-IV disorders in the National Comorbidity Survey Replication. Arch Gen Psychiatry. (2005) 62:617-27. doi: 10.1001/archpsyc.62.6.617

35. De Micco R, Russo A, Tedeschi G, Tessitore A. Impulse control behaviors in Parkinson's disease: drugs or disease? Contribution from imaging studies. Front Neurol. (2018) 9:893. doi: 10.3389/fneur.2018.00893

36. Smith KM, Xie SK, Daniel Weintraub D. Incident impulse control disorder symptoms and dopamine transporter imaging in Parkinson disease. J Neurol Neurosurg Psychiatry. (2016) 87:864-70. doi: 10.1136/jnnp-2015-311827

37. Driver-Dunckley E, Samanta J, Stacy M. Pathological gambling associated with dopamine agonist therapy in Parkinson's disease. Neurology. (2003) 61:422-3. doi: 10.1212/01.WNL.0000076478.45005.EC

38. Maia AF, Pinto AS, Barbosa ER, Menezes PR, Miguel EC. Obsessivecompulsive symptoms, obsessive-compulsive disorder, and related disorders in Parkinson's disease. J Neuropsychiatry Clin Neurosci. (2003) 15:371-4. doi: 10.1176/jnp.15.3.371

39. Sarathchandran P, Soman S, Sarma G, Krishnan S, Kishore A. Impulse control disorders and related behaviors in Indian patients with Parkinson's disease. Mov Disord. (2013) 28:1901-2. doi: 10.1002/mds.25557
40. Rodríguez-Violante M, González-Latapi P, Cervantes-Arriaga A, CamachoOrdoñez A, Weintraub D. Impulse control and related disorders in Mexican Parkinson's disease patients. Parkinsonism Relat Disord. (2014) 20:907-10. doi: 10.1016/j.parkreldis

41. Rizos A, Sauerbier A, Antonini A, Weintraub D, Martinez-Martin P, Kessel $B$, et al. European multicentre survey of impulse control behaviours in Parkinson's disease patients treated with short- and long-acting dopamine agonists. Eur J Neurol. (2016) 23:1255-61. doi: 10.1111/ene.13034

42. Biundo R, Weis L, Abbruzzese G, Calandra-Buonaura G, Cortelli P, Jori MC, et al. Impulse control disorders in advanced Parkinson's disease with dyskinesia: the ALTHEA Study. Mov Disord. (2017) 32:1557-65. doi: $10.1002 / \mathrm{mds} .27181$

43. Weintraub D, Hoops S, Shea JA, Lyons KE, Pahwa R, Driver-Dunckley ED, et al. Validation of the questionnaire for impulsive-compulsive disorders in Parkinson's disease. Mov Disord. (2009) 24:1461-7. doi: 10.1002/mds.22571

44. Weintraub D, Mamikonyan E, Papay K, Shea JA, Xie SX, Siderowf A. Questionnaire for impulsive-compulsive disorders in Parkinson's diseaserating scale. Mov Disord. (2012) 27:242-7. doi: 10.1002/mds.24023

45. Martinez-Martin P, Rodriguez-Blazquez C, Catalan MJ, EDIS StudyGroup. Independent and complementary validation of the QUIP-RS in advanced Parkinson's disease. Mov Disord Clin Pract. (2018) 5:341-2. doi: $10.1002 / \mathrm{mdc} 3.12603$

46. Probst CC, Winter LM, Möller B, Weber H, Weintraub D, Witt $\mathrm{K}$, et al. Erratum to: validation of the questionnaire for impulsivecompulsive disorders in Parkinson's disease (QUIP) and the QUIPrating scale in a German speaking sample. J Neurol. (2015) 262:2200. doi: 10.1007/s00415-015-7882-5

47. Christenson GA, Faber RJ, Mitchell JE. Compulsive buying: descriptive characteristics and psychiatric comorbidity. JClin Psychiatry. (1994) 55:5-11.

48. Grant JE, Chamberlain SR, Odlaug BL. Clinical Guide to Obsessive Compulsive and Related Disorders. New York, NY: Oxford University Press (2014).

49. Chamberlain SR, Grant JE. Minnesota Impulse Disorders Interview (MIDI): Validation of a structured diagnostic clinical interview for impulse control disorders in an enriched community sample. Psychiatry Res. (2018) 265:27983.doi: 10.1016/j.psychres.2018.05.006

50. Cabrini S, Baratti M, Bonfa F, Cabri G, Uber E, Avanzi N. Preliminary evaluation of the DDS-PC inventory: a new tool to assess impulsive-compulsive behaviours associated to dopamine replacement therapy in Parkinson's disease. Neurol Sci. (2009) 30:307-13. doi: 10.1007/s10072-009-0101-3

51. Goetz CG, Tilley BC, Shaftman SR, Stebbins GT, Fahn S, MartinezMartin P, et al. Movement Disorder Society-sponsored revision of the unified Parkinson's disease rating scale (MDS-UPDRS): scale presentation and clinimetric testing results. Mov Disord. (2008) 23:2129-70. doi: $10.1002 / \mathrm{mds} .22340$

52. Patton JH, Stanford MS, Barratt ES. Factor structure of the Barratt impulsiveness scale. J Clin Psychol. (1995) 51:768-74. doi: 10.1002/10974679(199511)51:6<768::AID-JCLP2270510607>3.0.CO;2-1

53. Martínez-Loredo V, Fernández-Hermida JR, Fernández-Artamendi S, Carballo JL, García-Rodríguez O. Spanish adaptation and validation of the Barratt Impulsiveness Scale for early adolescents (BIS-11-A). Int J Clin Health Psychol. (2015) 15:274-82. doi: 10.1016/j.ijchp.2015.07.002

54. Ellouze F, Ghaffari O, Zouari O, Zouari B, M'rad MF. Validation of the dialectal Arabic version of Barratt's impulsivity scale, the BIS-11. Encephale. (2013) 39:13-8. doi: 10.1016/j.encep.2012.06.034

55. von Diemen L, Szobot CM, Kessler F, Pechansky F. Adaptation and construct validation of the Barratt Impulsiveness Scale (BIS 11) to Brazilian Portuguese for use in adolescents. Braz J Psychiatry. (2007) 29:153-6. doi: 10.1590/S1516-44462006005000020

56. Rieu I, Martinez-Martin P, Pereira B, De Chazeron I, Verhagen Metman $\mathrm{L}$, Jahanshahi $\mathrm{M}$, et al. International validation of a behavioral scale in Parkinson's disease without dementia. Mov Disord. (2015) 30:705-13. doi: $10.1002 / \mathrm{mds} .26223$

57. du Toit PL, van Kradenburg J, Niehaus D, Stein DJ. Comparison of obsessivecompulsive disorder patients with and without comorbid putative obsessivecompulsive spectrum disorders using a structured clinical interview. Compr Psychiatry. (2001) 4:291-300. doi: 10.1053/comp.2001.24586 
58. Okai D, Askey-Jones S, Mack J, Martin A, Chaudhuri KR, Samuel M, et al. Parkinson's impulse-control scale for the severity rating of impulse-control behaviors in Parkinson's Disease: a semistructured clinical assessment tool. Mov Disord Clin Pract. (2016) 3:494-9. doi: 10.1002/mdc3.12316

59. Joutsa J, Martikainen K, Vahlberg $\mathrm{T}$, Voon V, Kaasinen V. Impulse control disorders and depression in Finnish patients with Parkinson's disease. Parkinsonism Relat Disord. (2012) 18:155-60. doi: 10.1016/j.parkreldis.2011.09.007

60. Voon V, Napier TC, Frank MJ, Sgambato-Faure V, Grace AA, RodriguezOroz $\mathrm{M}$, et al. Impulse control disorders and levodopa-induced dyskinesias in Parkinson's disease: an update. Lancet Neurol. (2017) 16:238-50. doi: 10.1016/S1474-4422(17)30004-2

61. Lee JY, Jeon B, Koh SB, Yoon WT, Lee HW, Kwon OD, et al. Behavioural and trait changes in parkinsonian patients with impulse control disorder after switching from dopamine agonist to levodopa therapy: results of REIN-PD trial. J Neurol Neurosurg Psychiatry. (2018) 0:1-8. doi: 10.1136/jnnp-2018-318942

62. Callesena MB, Scheel-Krugerb J, Kringelbach ML, Møllera A. A systematic review of impulse control disorders in Parkinson's disease. J Parkinsons Dis. (2013) 3:105-38. doi: 10.3233/JPD-120165

63. Rossi M, Bruno V, Arena J, Cammarota Á, Merello M. Challenges in PD patient management after DBS: a pragmatic review. Mov Disord Clin Pract. (2018) 5:246-54. doi: 10.1002/mdc3.12592

64. Houeto JL, Magnard R, Dalley JW, Belin D, Carnicella S. Trait impulsivity and anhedonia: two gateways for the development of impulse control disorders in Parkinson's disease? Front Psychiatry. (2016) 7:91. doi: 10.3389/fpsyt.2016.00091

65. Cilia R, van Eimeren T. Impulse control disorders in Parkinson's disease: seeking a roadmap toward a better understanding. Brain Struct Funct. (2011) 216:289-99. doi: 10.1007/s00429-011-0314-0

66. Vriend C, Pattij T, van der Werf YD, Voorn P, Booij J, Rutten S, et al. Depression and impulse control disorders in Parkinson's disease: two sides of the same coin? Neurosci Biobehav Rev. (2014) 38:60-71. doi: 10.1016/j.neubiorev.2013.11.001

67. Siri C, Cilia R, Reali E, Pozzi B, Cereda E, Colombo A, et al. Long-term cognitive follow-up of Parkinson's disease patients with impulse control disorders. Mov Disord. (2015) 30:696-704. doi: 10.1002/mds.26160

68. Vitale C, Santangelo G, Trojano L, Verde F, Rocco M, Grossi D, et al. Comparative neuropsychological profile of pathological gambling, hypersexuality, and compulsive eating in Parkinson's disease. Mov Disord. (2011) 26:830-6. doi: 10.1002/mds.23567

69. Siri C, Cilia R, De Gaspari D, Canesi M, Meucci N, Zecchinelli AL, et al. Cognitive status of patients with Parkinson's disease and pathological gambling. J Neurol. (2010) 257:247-52. doi: 10.1007/s00415-009-5301-5

70. Cormier-Dequaire F, Bekadar S, Anheim M, Lebbah S, Pelissolo A, Krack P, et al. Suggestive association between OPRM1 and impulse control disorders in Parkinson's disease. Mov Disord. (2018) 33:1878-86. doi: $10.1002 / \mathrm{mds} .27519$

71. Zainal Abidin S, Tan EL, Chan SC, Jaafar A, Lee AX, Abd Hamid MH, et al. DRD and GRIN2B polymorphisms and their association with the development of impulse control behaviour among Malaysian Parkinson's disease patients. BMC Neurol. (2015) 15:59. doi: 10.1186/s12883-015-0316-2

72. Erga AH, Dalen I, Ushakova A, Chung J, Tzoulis C, Tysnes O, et al. Dopaminergic and opioid pathways associated with impulse control disorders in Parkinson's disease. Front Neurol. (2018) 9:109. doi: 10.3389/fneur.2018.00109

73. Krishnamoorthy S, Rajan R, Banerjee M, Kumar H, Sarma G, Krishnan $S$, et al. Dopamine D3 receptor Ser9Gly variant is associated with impulse control disorders in Parkinson's disease patients. Parkinsonism Relat Disord. (2016) 30:13-7. doi: 10.1016/j.parkreldis.2016.06.005

74. Cardinal RN, Parkinson JA, Hall J, Everitt BJ. Emotion and motivation: the role of the amygdala, ventral striatum, and prefrontal cortex. Neurosci Biobehav Rev. (2002) 26:321-52. doi: 10.1016/S0149-7634 (02)0 0007-6

75. Brewer J, Potenza M. The neurobiology and genetics of impulse control disorders: relationships to drug addictions. Biochem Pharmacol. (2008) 75:63-75. doi: 10.1016/j.bcp.2007.06.043

76. van Oosten RV, Verheij MM, Cools AR. Bilateral nigral 6hydroxydo-pamine lesions increase the amount of extracellular dopamine in the nucleus accumbens. Exp Neurol. (2005) 191:24-32. doi: 10.1016/j. expneurol.2004.09.004

77. Buckholtz JW, Treadway MT, Cowan RL, Woodward ND, Li R, Ansari MS, et al. Dopaminergic network differences in human impulsivity. Science. (2010) 329:532. doi: 10.1126/science. 1185778

78. Dalley JW, Fryer TD, Brichard L, Robinson ES, Theobald DE, Laane K, et al. Nucleus accumbens D2/3 receptors predict trait impulsivity and cocaine rein-forcement. Science. (2007) 315:1267-70. doi: 10.1126/science.1137073

79. Claassen D, van den Wildenberg W, Ridderinkhof K, Jessup C, Harrison M, Wooten $\mathrm{G}$, et al. The risky business of dopamine agonists in Parkinson's disease and impulse control disorders. Behav Neurosci. (2011) 125:492-500. doi: 10.1037/a0023795

80. Keeler JF, Pretsell DO, Robbins TW. Functional implications of dopamine D1 vs. D2 receptors: a 'prepare and select' model of the striatal direct vs. indirect pathways. Neuroscience. (2014) 282:156-75. doi: 10.1016/j.neuroscience.2014.07.021

81. Ramdave S, Dawson A, Carter A, Dissanayaka NNW. Unmasking neurobiological commonalities between addictive disorders and impulse control disorders in Parkinson's disease. Brain Imaging Behav. (2019) 1:e00041-7. doi: 10.1007/s11682-019-00041-7

82. Meyer GM, Spay C, Laurencin C, Ballanger B, Sescousse G, Boulinguez P. Functional imaging studies of impulse control disorders in Parkinson's disease need a stronger neurocognitive footing. Neurosci Biobehav Rev. (2019) 98:164-76. doi: 10.1016/j.neubiorev.2019.01.008

83. Biundo R, Formento-Dojot P, Facchini S, Vallelunga A, Ghezzo L, Foscolo $\mathrm{L}$, et al. Brain volume changes in Parkinson's disease and their relationship with cognitive and behavioural abnormalities. J Neurol Sci. (2011) 310:64-9. doi: 10.1016/j.jns.2011.08.001

84. Biundo R, Weis L, Facchini S, Formento-Dojot P, Vallelunga A, Pilleri M, et al. Patterns of cortical thickness associated with impulse control disorders in Parkinson's disease. Mov Disord. (2015) 30:688-95. doi: $10.1002 / \mathrm{mds} .26154$

85. Cerasa A, Salsone M, Nigro S, Chiriaco C, Donzuso G, Bosco D, et al. Cortical volume and folding abnormalities in Parkinson's disease patients with pathological gambling. Parkinsonism Relat Disord. (2014) 20:1209-14. doi: 10.1016/j.parkreldis.2014.09.001

86. Imperiale F, Agosta F, Canu E, Markovic V, Inuggi A, Jecmenica-Lukic M, et al. Brain structural and functional signatures of impulsive-compulsive behaviours in Parkinson's disease. Mol Psychiatry. (2018) 23:459-66. doi: 10.1038/mp.2017.18

87. Markovic V, Agosta F, Canu E, Inuggi A, Petrovic I, Stankovic I, et al. Role of habenula and amygdala dysfunction in Parkinson disease patients with punding. Neurology. (2017) 88:2207-15. doi: 10.1212/WNL.0000000000004012

88. Pellicano C, Niccolini F, Wu K, O’Sullivan SS, Lawrence AD, Lees AJ, et al. Morphometric changes in the reward system of Parkinson's disease patients with impulse control disorders. J Neurol. (2015) 262:2653-61. doi: 10.1007/s00415-015-7892-3

89. Ricciardi L, Lambert C, De Micco R, Morgante F, Edwards M. Can we predict development of impulsive-compulsive behaviours in Parkinson's disease? J Neurol Neurosurg Psychiatry. (2018) 89:476-81. doi: 10.1136/jnnp-2017-317007

90. Ruitenberg MFL, Wu T, Averbeck BB, Chou KL, Koppelmans V, Seidler RD. Impulsivity in Parkinson's disease is associated with alterations in affective and sensorimotor striatal networks. Front Neurol. (2018) 9:279. doi: 10.3389/fneur.2018.00279

91. Tessitore A, Santangelo G, De Micco R, Vitale C, Giordano A, Raimo S, et al. Cortical thickness changes in patients with Parkinson's disease and impulse control disorders. Parkinsonism Relat Disord. (2016) 24:119-25. doi: 10.1016/j.parkreldis.2015.10.013

92. Yoo HB, Lee JY, Lee JS, Kang H, Kim YK, Song IC, et al. Whole-brain diffusion-tensor changes in parkinsonian patients with impulse control disorders. J Clin Neurol. (2015) 11:42-7. doi: 10.3988/jcn.2015.11.1.42

93. Canu E, Agosta F, Markovic V, Petrovic I, Stankovic I, Imperiale $\mathrm{F}$, et al. White matter tract alterations in Parkinson's disease patients with punding. Parkinsonism Relat Disord. (2017) 43:85-91. doi: 10.1016/j.parkreldis.2017.07.025

94. Mojtahed Zadeh M, Ashraf-Ganjouei A, Ghazi Sherbaf F, Haghshomar M, Aarabi MH. White matter tract alterations in drug-naïve Parkinson's 
disease patients with impulse control disorders. Front Neurol. (2018) 9:163. doi: 10.3389/fneur.2018.00163

95. Carriere N, Lopes R, Defebvre L, Delmaire C, Dujardin K. Impaired corticostriatal connectivity in impulse control disorders in Parkinson disease. Neurology. (2015) 84:1-8. doi: 10.1212/WNL.0000000000001619

96. Tessitore A, De Micco R, Giordano A, di Nardo F, Caiazzo G, Siciliano $\mathrm{M}$, et al. Intrinsic brain connectivity predicts impulse control disorders in patients with Parkinson's disease. Mov Disord. (2017) 32:1710-9. doi: $10.1002 / \mathrm{mds} .27139$

97. Tessitore A, Santangelo G, De Micco R, Giordano A, Raimo S, Amboni $\mathrm{M}$, et al. Resting-state brain networks in patients with Parkinson's disease and impulse control disorders. Cortex. (2017) 94:63-72. doi: 10.1016/j.cortex.2017.06.008

98. Claassen DO, Stark AJ, Spears CA, Petersen K, van Wouwe N, Kessler R et al. Mesocorticolimbic hemodynamic response in Parkinson's diseases patients with compulsive behaviors. Mov Disord. (2017) 32:1574-83. doi: $10.1002 / \mathrm{mds} .27047$

99. Loane $\mathrm{C}, \mathrm{Wu} \mathrm{K}$, O'Sullivan SS, Lawrence AD, Woodhead Z, Lees AJ, et al. Psychogenic and neural visual-cue response in PD dopamine dysregulation syndrome. Parkinsonism Relat Disord. (2015) 21:1336-41. doi: 10.1016/j.parkreldis.2015.09.042

100. Petersen K, Van Wouwe N, Stark A, Lin YC, Kang H, Trujillo-Diaz P, et al. Ventral striatal network connectivity reflects reward learning and behavior in patients with Parkinson's disease. Hum Brain Mapp. (2018) 39:509-21. doi: $10.1002 / \mathrm{hbm} .23860$

101. Politis M, Loane C, Wu K, O'Sullivan SS, Woodhead Z, Kiferle L, et al. Neural response to visual sexual cues in dopamine treatment-linked hypersexuality in Parkinson's disease. Brain. (2013) 136:400-11. doi: 10.1093/brain/aws326

102. Rao H, Mamikonyan E, Detre JA, Siderowf AD, Stern MB, Potenza MN, et al. Decreased ventral striatal activity with impulse control disorders in Parkinson's disease. Mov Disord. (2010) 25:1660-9. doi: 10.1002/mds.23147

103. Voon V, Pessiglione M, Brezing C, Gallea C, Fernandez HH, Dolan RJ, et al. Mechanisms underlying dopamine-mediated reward bias in compulsive behaviors. Neuron. (2010) 65:135. doi: 10.1016/j.neuron.2009.12.027

104. Voon V, Gao J, Brezing C, Symmonds M, Ekanayake V, Fernandez H, et al. Dopamine agonists and risk: impulse control disorders in Parkinson's disease. Brain. (2011) 134:1438-46. doi: 10.1093/brain/awr080

105. Evans AH, Pavese N, Lawrence AD, Tai YF, Appel S, Doder M, et al. Compulsive drug use linked to sensitized ventral striatal dopamine transmission. Ann Neurol. (2006) 59:852-8. doi: 10.1002/ana.20822

106. O'Sullivan SS, Wu K, Politis M, Lawrence AD, Evans AH, Bose SK, et al. Cue-induced striatal dopamine release in Parkinson's diseaseassociated impulsive-compulsive behaviours. Brain. (2011) 134:969-78. doi: 10.1093/brain/awr003

107. Steeves TDL, Miyasaki J, Zurowski M, Lang AE, Pellecchia G, van Eimeren $\mathrm{T}$, et al. Increased striatal dopamine release in parkinsonian patients with pathological gambling: A 11C raclopride PET study. Brain. (2009) 132:137685. doi: 10.1093/brain/awp054

108. Wu K, Politis M, O'Sullivan SS, Lawrence AD, Warsi S, Bose S, et al. Single versus multiple impulse control disorders in Parkinson's disease: an 11C-raclopride positron emission tomography study of reward cue-evoked striatal dopamine reléase. J Neurol. (2015) 262:1504-14. doi: $10.1007 / \mathrm{s} 00415-015-7722-7$

109. Payer DE, Guttman M, Kish SJ, Tong J, Strafella A, Zack M, et al. $\left[{ }^{11} \mathrm{C}\right]-$ (+)-PHNO PET imaging of dopamine $\mathrm{D}(2 / 3)$ receptors in Parkinson's disease with impulse control disorders. Mov Disord. (2015) 30:160-6. doi: $10.1002 / \mathrm{mds} .26135$

110. Ray NJ, Miyasaki JM, Zurowski M, Ko JH, Cho SS, Pellecchia G, et al. Extrastriatal dopaminergic abnormalities of DA homeostasis in Parkinson's patients with medication-induced pathological gambling: a [11C] FLB-457 and PET study. Neurobiol Dis. (2012) 48:519-25. doi: 10.1016/j.nbd.2012.06.021

111. Joutsa J, Martikainen K, Niemelä S, Johansson J, Forsback S, Rinne JO, et al. Increased medial orbitofrontal [18F]fluorodopa uptake in Parkinsonian impulse control disorders. Mov Disord. (2012) 27:778-82. doi: $10.1002 / \mathrm{mds} .24941$
112. van Eimeren T, Pellecchia G, Cilia R, Ballanger B, Steeves TD, Houle S, et al. Drug-induced deactivation of inhibitory networks predicts pathological gambling in PD. Neurology. (2010) 75:1711-6. doi: 10.1212/WNL.0b013e3181fc27fa

113. Lee JY, Seo SH, Kim YK, Yoo HB, Kim YE, Song IC, et al. Extrastriatal dopaminergic changes in Parkinson's disease patients with impulse control disorders. J Neurol Neurosurg Psychiatry. (2014) 85:23-30. doi: 10.1136/jnnp-2013-305549

114. Verger A, Klesse E, Chawki MB, Witjas T, Azulay JP, Eusebio A, et al. Brain PET substrate of impulse control disorders in Parkinson's disease: A metabolic connectivity study. Hum Brain Mapp. (2018) 39:3178-86. doi: $10.1002 / \mathrm{hbm} .24068$

115. Cilia R, Siri C, Marotta G, Isaias IU, De Gaspari D, Canesi M, et al. Functional abnormalities underlying pathological gambling in Parkinson disease. Arch Neurol. (2008) 65:1604-11. doi: 10.1001/archneur.65.12.1604

116. Cilia R, Ko JH, Cho SS, van Eimeren T, Marotta G, Pellecchia G, et al. Reduced dopamine transporter density in the ventral striatum of patients with Parkinson's disease and pathological gambling. Neurobiol Dis. (2010) 39:98-104. doi: 10.1016/j.nbd.2010.03.013

117. Voon V, Rizos A, Chakravartty R, Mulholland N, Robinson S, Howell NA, et al. Impulse control disorders in Parkinson's disease: decreased striatal dopamine transporter levels. J Neurol Neurosurg Psychiatry. (2014) 85:14852. doi: 10.1136/jnnp-2013-305395

118. Vriend C, Nordbeck AH, Booij J, van der Werf YD, Pattij T, Voorn $\mathrm{P}$, et al. Reduced dopamine transporter binding predates impulse control disorders in Parkinson's disease. Mov Disord. (2014) 29:904-11. doi: $10.1002 / \mathrm{mds} .25886$

119. Premi E, Pilotto A, Garibotto V, Bigni B, Turrone R, Alberici A, et al. Impulse control disorder in PD: a lateralized monoaminergic frontostriatal disconnection syndrome? Parkinsonism Relat Disord. (2016) 30:62-6. doi: 10.1016/j.parkreldis.2016.05.028

120. van Eimeren $T$, Ballanger B, Pellecchia G, Miyasaki JM, Lang AE, Strafella AP. Dopamine agonists diminish value sensitivity of the orbitofrontal cortex: a trigger for pathological gambling in Parkinson's disease? Neuropsychopharmacoly. (2009) 34:2758-66. doi: 10.1038/sj.npp.npp2009124

121. Stark AJ, Smith CT, Lin YC, Petersen KJ, Trujillo P, van Wouwe NC, et al. Nigrostriatal and mesolimbic $\mathrm{D}(2 / 3)$ receptor expression in parkinson's disease patients with compulsive reward-driven behaviors. J Neurosci. (2018) 38:3230-9. doi: 10.1523/JNEUROSCI.3082-17.2018

122. Ryan SA, O'Sullivan SS. Impulsive-compulsive behaviours in Parkinson's disease-prevention is better than cure. Ir Med J. (2013) 106:162.

123. Ramirez-Zamora A, Gee L, Boyd J, Biller J. Treatment of impulse control disorders in Parkinson's disease: practical considerations and future directions. Expert Rev Neurother. (2016) 16:389-99. doi: 10.1586/14737175.2016.1158103

124. Brock P, Fisher JM, Hand A, Walker RW. Highlighting the goals for Parkinson's care: commentary on NICE guidelines for Parkinson's in adults (NG71). Age Ageing. (2018). doi: 10.1093/ageing/afy158. [Epub ahead of print].

125. Kim A, Kim YE, Kim HJ, Yun JY, Yang HJ, Lee WW, et al. A 7year observation of the effect of subthalamic deep brain stimulation on impulse control disorder in patients with Parkinson's disease. Parkinsonism Relat Disord. (2018) 56:3-8. doi: 10.1016/j.parkreldis.201 8.07.010

Conflict of Interest Statement: The authors declare that the research was conducted in the absence of any commercial or financial relationships that could be construed as a potential conflict of interest.

Copyright (c) 2019 Gatto and Aldinio. This is an open-access article distributed under the terms of the Creative Commons Attribution License (CC BY). The use, distribution or reproduction in other forums is permitted, provided the original author(s) and the copyright owner(s) are credited and that the original publication in this journal is cited, in accordance with accepted academic practice. No use, distribution or reproduction is permitted which does not comply with these terms. 